\title{
[7]
}

\section{Lives beyond the Workplace}

How do servants, members of their households, and people with whom they interact when not at work experience lives in a depressed economy beset by recurrent scarcities of basic consumer goods and runaway inflation? How do they manage economically, and what are their alternatives to domestic service? What kind of social life and leisure time do they have? And what of their employers-how are these questions answered for them? In this chapter I explore these questions, and discuss the action that servants have taken to improve their position vis-à-vis other members of the working class and in society at large. I also examine some of the implications that the persistence of domestic service has for the debate about development in Zambia today. My discussion centers on today's most typical domestic worker, the male general servant, but whenever it is relevant I highlight the different experiences of women servants.

\section{Domestic Service: A Way of Life?}

Given their substandard wages, how indeed do servants manage to make a living? A general servant receives an average monthly wage that is gone before he has purchased his own household's basic staples. A minimum monthly budget, featuring meat or fish twice a week as a complement to nshima, the maize porridge, plus very basic essentials, would in 1983 require K119 to feed a household of two adults and two children. Few servants come close to earning that, and many have more than two children and sometimes other dependents as well. The wages most servants receive barely cover the purchase of a minimum of basic necessities such as mealie 


\section{Colonial Legacies and Postcolonial Changes}

meal, charcoal, cooking oil, salt, sugar, soap, and detergent. If these necessities are bought, little if nothing remains for meat, relish, eggs, milk, bread, and tea not to mention clothes, school fees and uniforms or the expenses occasioned by the inevitable arrival of relatives.

To find the answer to the question, I asked two general servants I knew well to record their daily expenses, one for a two-month period, the other for three months. Their budgets are detailed in Appendix 2, as is the minimum monthly budget described above. There are several differences between the two servants. Edson, who kept his records for two months, was at the time a twenty-four-year-old general servant who had worked in the household of an expatriate Asian couple for five years. His wife, Gertrude, had recently been taken on part time; the madam suffered a back problem and was teaching Gertrude to cook Indian food to relieve herself from strenuous activity. Gertrude was also expected to do the general housework on Edson's day off. Theirs was the only Asian household in which I found an African woman cooking, and one in less than a handful of Asian households that employed African women in any capacity. Edson earned K75 and Gertrude K44 a month; Edson's wage was raised to K85 after the first month of his budget record. They had two children below school age, and Gertrude was pregnant with their third child. Euclid, who kept his records for three months, was a general servant in the household of a North American couple for whom he had worked for three years. He was thirty-five years old and recently remarried after a divorce; he and and his new wife had one small child. He earned K82 a month. Both these men had gone to school for about seven years. Their wives were barely literate.

Although they received different wages and the composition of their households varied, they had one thing in common with most of the servant households in my survey. Their income was insufficient to afford their households a minimum of necessities. In Edson's household, meat or fish was eaten approximately once a week, in Euclid's fish only. Their children hardly if ever got milk; most of the time they had to suffice with a diet of nshima and relish. The children beyond nursing age were undernourished. Judging from their budget records, Edson's household ate better than Euclid's. The difference was to some extent made up from Euclid's garden. $\mathrm{He}$, like some other servants, had access to a garden plot in or behind the employer's garden on which he grew vegetables and maize. It provided a limited supplement but not one sufficient to cover the household needs. Under these circumstances, the weekly ration money that some servants are given is used for food and to some extent tides them over to month's end; Euclid received a weekly ration of two Kwacha.

Did income-generating activities on the part of servants' wives help relieve the shortfall in wages? Even though Gertrude, and she was an exception, worked half time, her small wage did not make a large differ- 
ence in a low budget. Some, but very few, wives surveyed were occasionally asked to lend a hand with household chores for which they were paid on a piecework basis. In a few of the expatriate households, the work inside and outside the house was done by a servant couple who were paid separately. A few wives earned their own incomes, some as servants employed elsewhere and others engaging in small-scale vegetable trading in nearby markets or sewing dresses for sale from home. But the vast majority of servants' wives earned no money of their own. They cooked the meals in their own households, swept the quarters, took care of children, and otherwise "just sat" (Zambian-English term for the activity of persons who are not wage employed).

The male breadwinner is supposed to provide for everything his household needs. Although adult relatives from the extended family were accommodated in some of the servant households, most of them were on the lookout for work and they rarely contributed to the household's support. Their presence taxed the already meager resources of their hosts. A few menservants pursued income-generating activities on the side. A couple of them did tailoring work and one did tin-smithing. Their hope was to save money, to build a house in a compound or to set themselves up in business so that they could leave their servant jobs behind.

For most general servants, the employer's charity is the final recourse. Handouts of household necessities, leftover food, and new and used clothing are welcomed and come to be expected. In the mornings Edson and Gertrude got leftover tea, a slice of bread, and their oldest girl got milk and bread. Edson's employers regularly purchased the children's shoes. Both Edson's and Euclid's households received gifts at Christmas and presents when their employers returned from overseas leaves. But when assistance is not forthcoming, some servants help themselves and the problem of pilfering, if not outright theft, arises.

Alternatively or in addition, servants ask for advances from their pay to cover unanticipated expenses. Many servants, including Edson and Euclid, asked for pay advances regularly or borrowed from their employers and then paid back in installments. As debts accumulate, servants become more dependent on their employer's good will and hope that the debts will be written off. Sometimes they are, and for a while no further advances are given. Some employers establish a limit, often the amount of the servant's monthly wage, beyond which they do not permit borrowing. Once it is reached, a schedule of monthly payments is begun, during which time the servant is unable to borrow.

While many employers function as their servants' loan bank, some servants allocate some of their funds to a rotating credit system known as chilimba. Two (or more) persons who trust one another alternate in handing over an agreed-upon portion of their wage, for example, $\mathrm{K} 20$, to the 


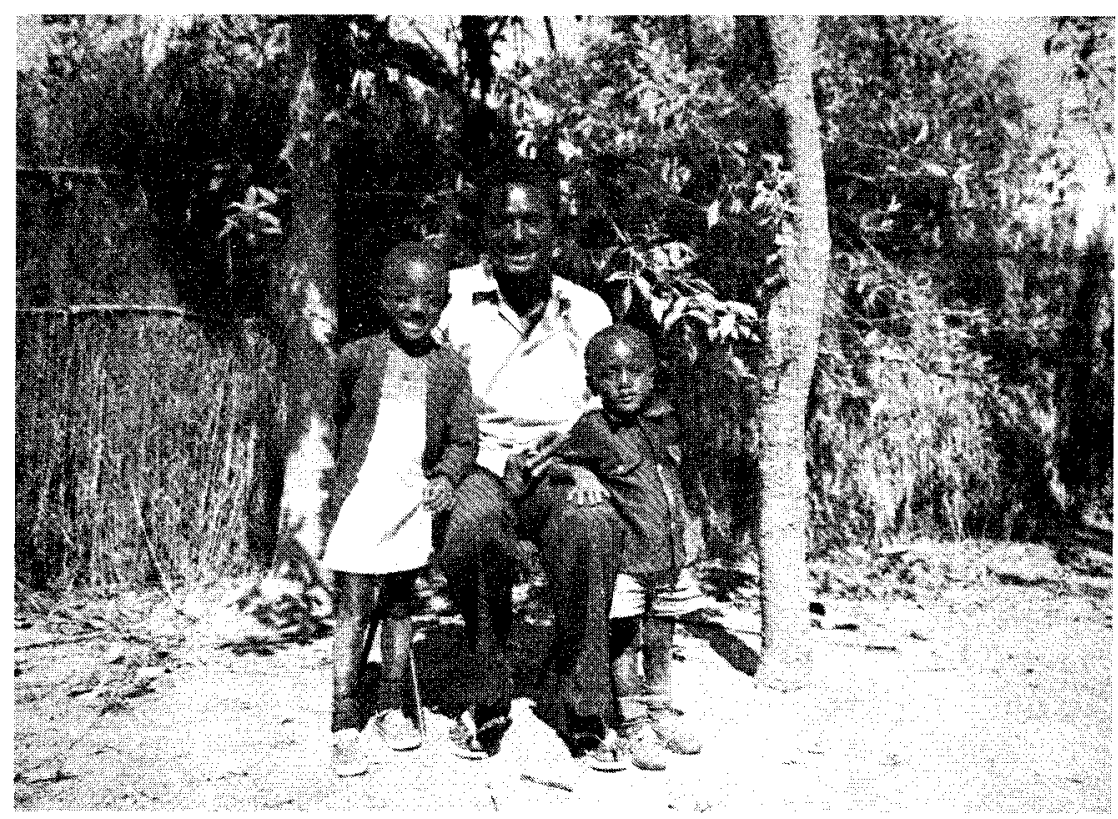

Edson Banda with Faides and Joe, Lusaka 1984. Author's photograph.

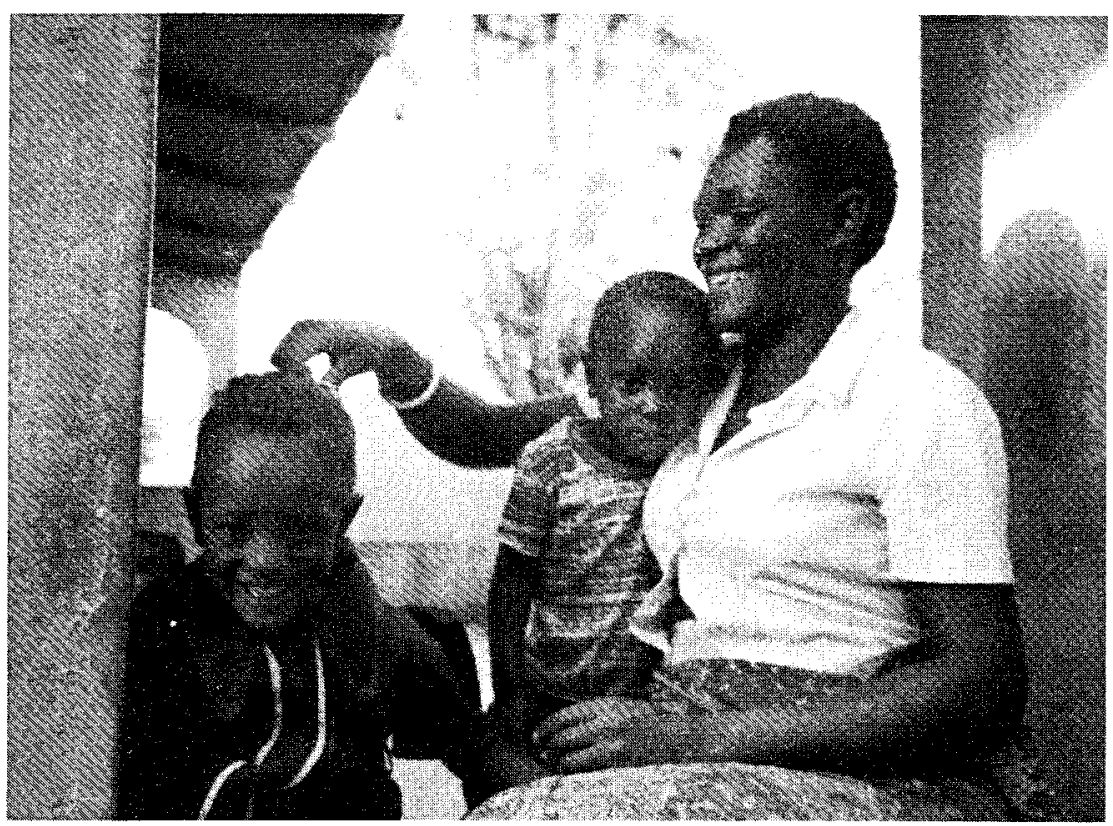

Gertrude Banda with Faides and Joe, Lusakla 1984. Author's photograph. 


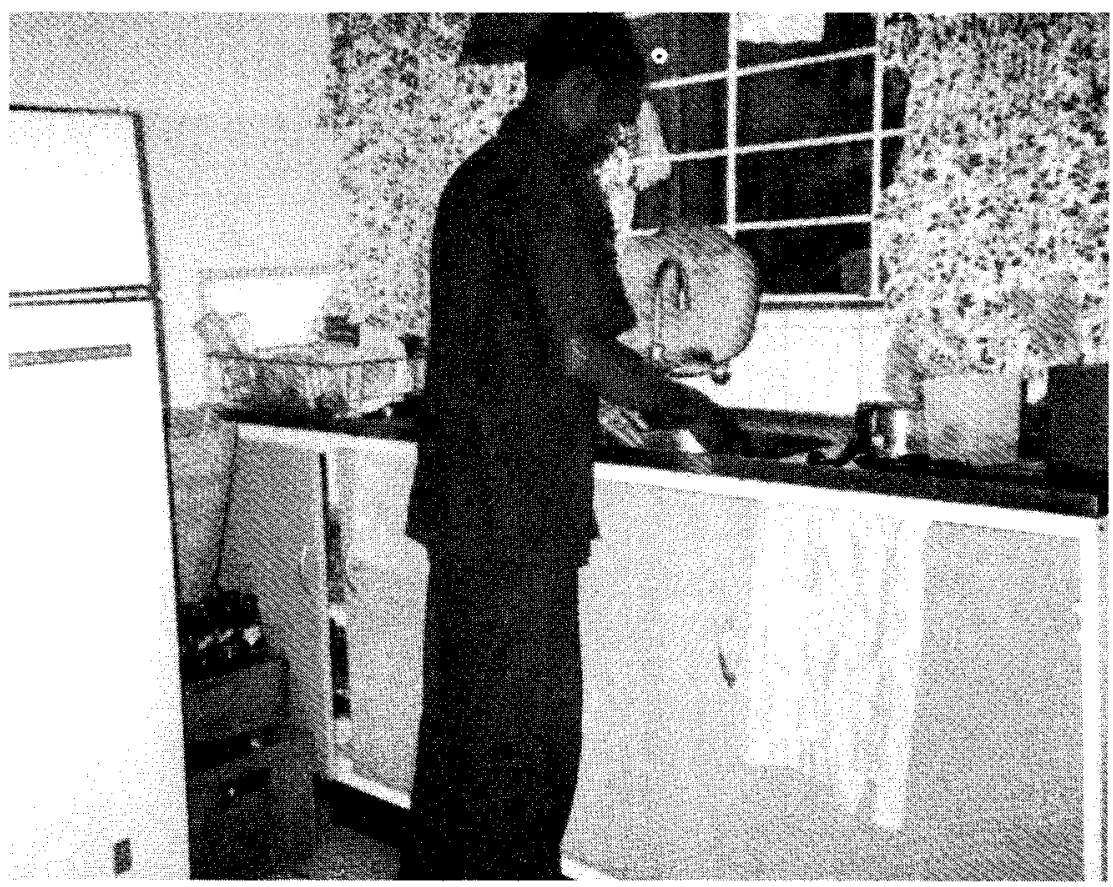

Euclid Nkumbula at work in the kitchen, Lusaka 1984. Author's photograph.

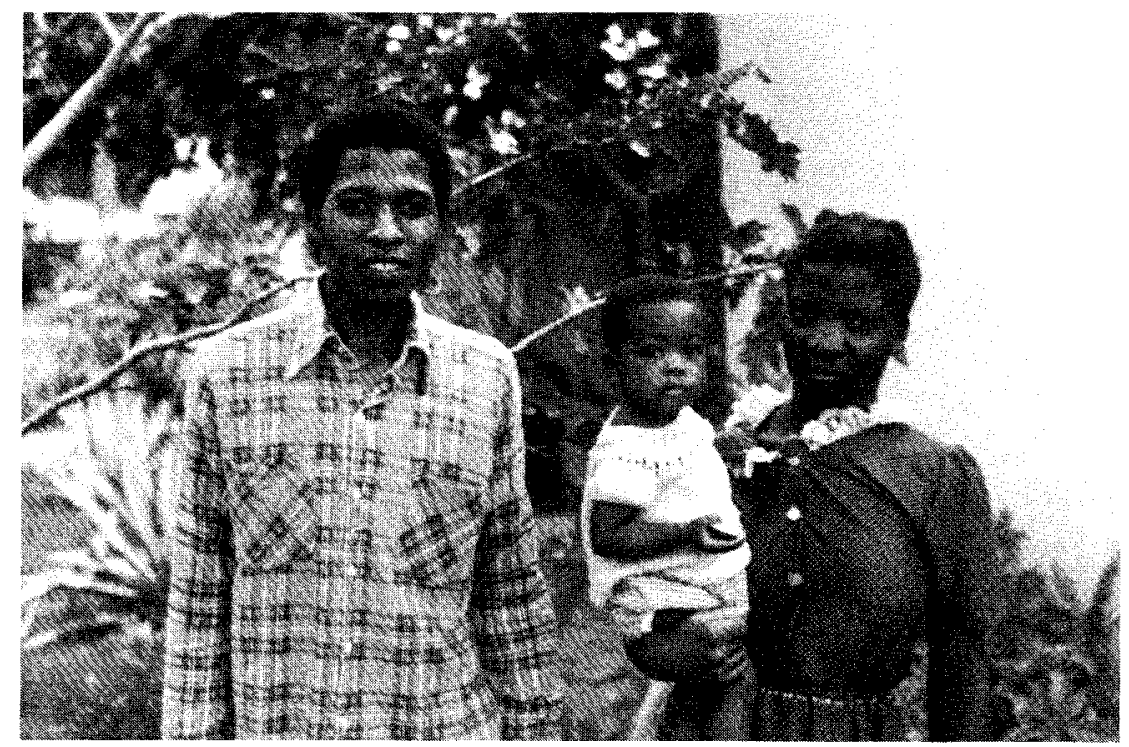

Euclid Nkumbula, daughter Nellie, and wife Betty, Lusaka 1984. From the collection of Henry Antkiewicz. Reproduced with permission. 
other every month. A servant involved in chilimba who receives a monthly wage of K70 keeps K50 from his own wage during the month it is his turn to hand over money to his partner. But every second month he has K20 in addition to his own wage. This extra enables him to some degree to meet the financing of larger purchases, clothes, for example, often in installments. In this way, chilimba may help to stretch the budget. Twenty-six percent of the servants in the survey practiced chilimba at the time of the interview. Many more had done so previously but had given it up for a variety of reasons, including the move of their partner or because they had been cheated. The servants who engaged in chilimba were not young people new to town but mainly older people, and proportionately more older women than menservants. Young servants in their first job would say that they did not know anyone they could trust enough to start chilimba.

Servants may also resort to a lending practice known as kaloba to meet such unexpected expenses as the funeral of a father for which the employer has refused an advance because he has helped cover expenses for the funerals of several relatives. According to kaloba practices, borrowed money has to be repaid within a month at 50 percent interest. To repay it, access to chilimba funds is convenient, as is the prospect of a pay advance in next month, although the latter alternative makes the servant more dependent on the employer than the former. A couple of servants in my survey had turned kaloba into a profit-making venture. They used their access to wage advances to develop a loan-shark business. Borrowing from their employer in the middle of the month, they lent the money to someone else at kaloba rates. When they received the repayment with interest at the next midmonth, they returned the amount owed to the employer and pocketed the profit.

The chilimba system is not unique to servants. There is anecdotal evidence that it spread with migration during the colonial period. From Broken Hill in the late 1930s, Wilson reported that "nearly every African man . . , married or single, has a partner with whom he pools his wages, alternatively, each month," 1 and Epstein gives examples from the African township in Ndola on the copperbelt in mid-1950 . $^{2}$ The practice persists in today's low- to middle-income townships among various occupational groups such as orderlies, clerks, and secretaries. Chilimba, other rotating credit systems, ${ }^{3}$ and various borrowing arrangements in Zambia have not

1. Godfrey Wilson, "An Essay on the Economics of Detribalisation in Northern Rhodesia, Part 2," Rhodes-Livingstone Papers, no. 6 (1942), p. 77.

2. A. L. Epstein, Urbanization and Kinship: The Domestic Domain on the Copperbelt of Zambia 1950-1956 (New York: Academic Press, 1981), pp. 52-54.

3. Peter Hayward, personal communication, has noted two rotating credit systems among fishermen in Zambia: muyambiro and kamukole. 
been the subject of any inquiry in their own right. ${ }^{4}$ If they spread with the system of migratory labor, they may have arisen in response to the expansion of the cash nexus and have offered a practical financial arrangement understood by all in the multiethnic context of the growing colonial cities.

Chilimba and servants' use of a variety of borrowing systems provide evidence of the careful short- and long-term planning they apply in their attempt to make a living on scarce resources. "Stretching the money," as servants explain the function of chilimba, shows no lack of foresight. Such practices make available to servants the kind of credit they are unlikely to obtain in downtown banks because of lack of collateral. They also spare them from spending money on bus fares and wasting time in bank lines, for most banks are far away from the low-density residential areas in which most servants live and work. Euclid used his employer as a bank and loan association. He pursued a two-fold strategy: he asked his employer to retain part of his current wage as well as give him an advance on the next month's pay. These two transactions were carefully recorded in a book the employer kept for that purpose, and Euclid would often write notes when he wanted some of "his" money. Euclid knew the exact disposition of his money and corrected any errors in his employer's calculations. His accounts were intricate, for he earmarked funds from the two transactions for different purposes. Euclid used the "savings" from the regular wage on an intermittent basis throughout the month to pay for food, thus ensuring his urban household a bare minimum. He occasionally used advances from the next month's pay for installments on the purchase of a cow that he kept in his mother's village. He was a matrilineal Tonga from the Southern Province and was presumably seeking to accumulate a nest egg to offer him some security when he no longer worked in town. By contrast, Edson's household spent all of its income on living expenses every month. He was a matrilineal Nsenga from the Eastern Province who had neither land nor cattle; his mother had divorced his father and remarried in the city; there were no uncles left in the village, and Edson would have a hard time making customary claims on land.

Most servants struggle to make ends meet. To ease their struggle, some servants "farm out" children to country relatives. Some servants who up-

4. In an article that summarizes information on this topic from across Africa, the authors mention chilimba in Zambia and Zimbabwe but provide no substantive information on the arrangement. See Marvin P. Miracle, Diane S. Miracle, and Laurie Cohen, "Informal Savings Mobilization in Africa," Economic Development and Cultural Change 28 (1980): 701-724. Most of our African examples of rotating credit associations come from West Africa. For an excellent and detailed study of this subject in another part of the world, see Carlos G. VelezIbanez, Bonds of Mutual Trust: The Cultural Systems of Rotating Credit Associations among Urban Mexicans and Chicanos (New Brunswick, N.J.: Rutgers University Press, 1983). 


\section{Colonial Legacies and Postcolonial Changes}

hold use rights to land in the villages let their wives alternate between town and countryside, tending fields during the rainy season and keeping house during the dry season. But most servants have neither land nor cattle. And some do not have relatives who are able to keep their children. Many of them ended up in service jobs in the first place because of family circumstances that prevented them from progressing in school. And few of the servants I met had been able to save anything from their meager wages.

\section{Occupational Alternatives}

In their own view and that of fellow Zambians, servants lead miserable lives, doing a job from which there is nothing to gain and which has no future. When asked if she would consider taking a job as a servant, a woman resident in a high-density township answered emphatically, "Over my dead body!" She was of South African background, and had had her first wage-labor experience as a domestic servant in the south: there was "no way" she would do it again. Women, as I discussed earlier, enter domestic service as a last resort. For most, the preferred alternative is to be a wife and mother in one's own household. Yet economic pressures and strained marital relations provoke many women to seek some means of making money. When they do, they usually do not turn to domestic service but to trade and vending. Such activity allows them to continue to supervise their households, while in most cases they earn more than they would from domestic service. My previous work in Lusaka has shown how, over the course of their adult lives, many women intermittently conduct small-scale trades from their homes, in the streets and at markets. ${ }^{5}$ No matter how small-scale their activity is, however, they need startup capital and the lack of it may force some women to seek work as servants: but this is a temporary measure.

Domestic service is an occupation without a future. Servants often feel trapped, with no options. They do not make enough money to set themselves up in a craft or trade, and in addition, their working hours do not leave them time to engage in any other money-earning activity. Only few can expect to move up in the ranks of the servant hierarchy, to become cooks in managerial households on company payroll. Once there, the pay compares unfavorably to that of the lowest-paid unionized worker on the payroll in the same company. Thus most servants depend for their future on their employers. Some well-intentioned households assist servants in

5. I have discussed women's trading and household activities in several articles, among them "The Urban Informal Sector as a Development Issue: Poor Women and Work in Lusaka, Zambia," Urban Anthropology 9 (1980): 199-225, and "Negotiating Sex and Gender in Urban Zambia," Journal of Southern African Studies 10 (1984): 219-238. 
getting a driver's license; others secure them jobs in their company as janitors, messengers, orderlies, hospital attendants, or as cooks or waiters in hotels, bars, and private clubs. Such jobs are much preferred over domestic service because of their regulated hours, higher wages, and stipulated benefits. These jobs comprised the main avenue for upward mobility among the former servants I interviewed in Mtendere township.

The general consensus among former servants as well as nonservants was that they would rather have their children return to the rural areas to farm than see them employed as servants. When they make such statements, members of the older generation are envisioning a nonexistent ideal; they forget that they themselves left their villages to seek better economic opportunities in towns. Living conditions and economic prospects in the rural areas have so deteriorated in many regions ${ }^{6}$ that returning to them is at present a worse option than the urban job as a servant. Though some servants have rights to land in their villages and some even have rights to cattle, resettling in a rural area requires resources-to purchase seed and fertilizer, perhaps to build a house-that most servants do not have. The growing disparity in the cities between the few who are well situated and the many who have nothing to sell but their labor power is increasingly becoming characteristic of the rural areas as well. ${ }^{7}$ The few resources a returned townsman would bring to his village are likely to disappear quickly, given customary claims on his generosity. If he keeps his resources to himself and appears to be stingy, he may cause envy among his relatives. In some cases, these tensions have resulted in accusations of witchcraft. If the migrant goes back to the city (as many, like Zacchi, eventually do), he is likely to return there in poorer health than when he left and, without savings; he will have few other options but to reenter the domestic service market. It is a typical scenario and helps to explain why 45 percent of the servants I surveyed did not keep up connections with their villages of birth or their parents' home villages. One-third of these servants had been born in towns, and the rest had not been back to the village since their first departure. The lack of economic means and poor education that precipitated their departure also prevent them from returning to the villages.

Some young menservants who are recent entrants into the paid labor force study for their school-leaving certificates when off duty, still hoping that school credentials will open up new doors. Others have hopes of becoming drivers, as few formal credentials are necessary for the job. But positions as drivers are not easy to find-this occupation claimed the third

6. Peter Stromgaard, "A Subsistence Society under Pressure: The Bemba of Northern Zambia," Africa 55 (1985): 39-59.

7. Thayer Scudder and Elizabeth Colson, Secondary Education and the Formation of an Elite: The Impact of Education on Gwembe District (New York: Academic Press, 1980). 


\section{Colonial Legacies and Postcolonial Changes}

largest number of registrants at the labor exchange in September 1983. The largest number of job seekers looked for work in domestic service, and about half of them did find places.

Domestic service remains the only wage-paying alternative to which the young aspiring job-seekers return once their attempts to escape it have failed. Many of the young men I surveyed had left the job after an initial stint of less than a year. Some went back to their villages, only to return to the city. Some held various jobs as general workers, all of them temporary (it is well known that a number of Lusaka firms and companies take on temporary workers to cut costs). Some young men took jobs as security guards but left this higher paying occupation (at least when compared with domestic service) because of its awkward hours and the dangers associated with it. Within a couple of years, these young men had returned to the servant ranks. And there many of them are likely to remain. In the words of a twenty-four-year-old general servant with a wife and two children who was in his second job: "This is the only job for people like us who are not educated. Once a servant, always a servant!"

Accommodation and handouts of food and clothing in addition to wages are probably sufficient factors to continue to attract workers to domestic service, especially newcomers fresh from the countryside who are unable to find housing in Lusaka's crowded townships. Compared with rural poverty, and with the irregularity of other available jobs and the uncertainties of self-employment, domestic service offers at the present time at least a regular income and a subsistence level of survival for many families. Most of these servants, rarely themselves the sons and daughters of servants, hoped to ensure with their limited means that their children would go to school and never have to enter the occupation. But such hopes were more realistic during the late colonial period, for education was the chief means of upward mobility for the first generation of young adults immediately after independence. Since then, the educational system has not expanded at a rate sufficient to accommodate all children of school age. Because of their substandard wages, servants will have a hard time sending their children through school even if they are lucky enough to get places for them. With the high dropout rate on the one hand and the increased requirements of job applicants for degrees and certificates on the other, parents have little certainty that their struggle for their children's education eventually will pay off.

\section{Fenced-in Lives}

Today's economic structure in Zambia enables a tiny segment of the population-but one of diverse ethnic composition-to enjoy what in the 
past would have been considered racial privileges: large houses and gardens, servants to attend to their needs, poolside parties, sundowners on the porch, and private clubs. Today's servant-keeping population does not form a socially united community. They have in common only that they all employ servants whom they rarely trust but require nonetheless for security reasons, and they all are inconvenienced by the inflationary economy and recurrent scarcities.

Life for the financially privileged is fraught with fear and lived in an atmosphere of paranoia: valuables are hidden away, property is locked up. To prevent their servants from stealing as well as from seeing how many things they own, many employers lock up closets, cupboards, and chests of drawers, and some lock up bedrooms and studies as soon as the servant has finished cleaning them. Some householders remove their best pots and pans, cutlery and plates from the kitchen every evening, locking them up in store-rooms or bedroom closets. Kitchen staples-cooking oil, rice, sugar, salt, tea-are regularly locked up away from the kitchen. Refrigerators and deep freezers are sometimes placed in back rooms rather than the kitchen and locked. Many householders do not display their valuables in the living room so that they are not within view from the outside. Television sets, videos, radios, stereos are put in the master bedroom at night, and some people lock their bedroom doors from the inside. Employers try not to have much cash in the house, while at the same time making sure that they do have some bank notes at hand just in case "the burglars" should come-on the assumption that it is wiser to hand over money than be beaten or shot. They devise "advance warning systems," for example, putting empty bottles on window sills which burglars might shatter as they try to break in. Some households sleep in relays, so that at least one person is awake and alert at all hours. If a burglary occurs, often people stay behind locked bedroom doors and let the thieves take the few things left in the living room and kitchen rather than confronting possibly armed men. Nightwatchmen and servants have little power to deter thieves, who may beat them up or simply offer them a cut of the take. Dogs kept outside may be killed or poisoned. Not all employers have telephones; even if there is a phone, it may not work; and if the phone works, a call to the police station would make little difference. The police have too few cars, or gasoline might be unavailable, and so they would be unlikely to arrive at the scene before the burglars had gone. The police are notoriously ineffective in tracking down burglars after the fact. If they are caught, burglars are likely to be beaten, but when they recover from their bruises, they may simply go back to it again. While this is the worst scenario, all employers have experienced some aspect of it. Most urban residents go to bed fearing the night and worrying about what the morning will reveal.

Fear is not restricted to the house. Cars are burgled during the daytime; 


\section{Colonial Legacies and Postcolonial Changes}

people are robbed while waiting for the red light to change at one of Lusaka's few light-controlled intersections. (Stories abound of people being robbed from their cars at gunpoint and left to walk home at night in little or no clothing.)

Because of the general insecurity of living, a good deal of leisure time is spent at home, where now more entertainment takes place than during the colonial period. Expatriates and Zambians who can afford them have VCRs. Guests from across town tend to be invited for daytime gatherings during weekends. Informal visits and unannounced calls occur mostly before sunset. Dinner parties may feature guests predominantly from the immediate neighborhood, and those who come from a distance leave home fearing the drive and what they may encounter on their return. Many dislike this sense of being prisoners in their own homes and insist on going out from time to time to retain a wider sphere of interaction.

Lusaka offers a variety of entertainments appealing to expatriates, although many complain about the city's dearth of "culture." The amateur theater tradition that was started during the colonial period persists together with its club and bar. It regularly stages productions of both African and non-African pieces. The city has several movie houses that specialize in films glorifying the martial arts. The culture-promoting societies sponsored by national governments are present, too: the Alliance Française and the British Council. They, some of the foreign embassies that include representation from Eastern European and Asian countries, and the United States Information Service promote special events and some have libraries. There are also special-interest groups such as a Horticultural Society which sponsors yearly exhibits and competitions, a Wildlife Conservation Society, an Ornithological Society, and a variety of others. Attendance at most such events is predominantly non-Zambian.

Beyond their problems with servants, burglaries, and the country's economic ills, Lusaka's residents have little in common. Expatriates are likely to interact with Zambians at work, during work-related functions, and in civic and philanthropic groups such as Rotary International, the Jaycees, Round Table, and Lions, and when going to restaurants and bars. Those who are members of private sports clubs play tennis, squash, and golf, and drink beer in the club's bar with their Zambian fellow players. There is also a riding club, polo club, fencing club, and flying club whose memberships are predominantly expatriate. Dinner parties may feature a few Zambian colleagues, perhaps accompanied by wives. But many expatriates complain that it is difficult to establish close personal friendships with Zambians. Social invitations are rarely reciprocated; interests are said to differ. Those expatriates who have made efforts often leave the country with a sad feeling of never really having gotten to know the local population. Their knowledge of ordinary Zambians' way of life is limited to occasional car trips 


\section{Lives beyond the Workplace}

through a high-density area where they may have stopped briefly to bring, fetch, or search for a servant or buy beer during a shortage. And for some, the low-income areas function as "sights," which they point out to visitors new to the country.

Some expatriates' desire to "know the African" changes to "knowing Africa"-meaning the game parks, Victoria Falls, and exotic birds with which Zambia is richly endowed. Camping trips and visits to these places are the highlights of many expatriates' African experience in Zambia and they help create an image of an Africa that probably never was. In some of the game parks, visitors may rough it on walking safaris, sleeping for a few nights in huts or tents. Providing a break from the prisonlike existence in Lusaka, such trips feature specialized servants reminiscent of the colonial past: skilled cooks and inside servants in the lodges and tea boys among the inventory of walking safaris.

Not all expatriates who take jobs in Zambia are interested in getting to know the local population and exploring the region. Some (specifically the Asian expatriates) accept contracts in Zambia for the sole purpose of getting a job because of the glut of people with their skills and qualifications in their home countries. The response of one Asian woman in my survey reflects the attitude: "What is there to know?"

Asians, like the other regional or racial groups represented in my survey, socialized primarily with persons of their own group. These broad groups are comprised of a number of subgroups. The Asian population, for example, had several divisions of which the most marked were those between long-time residents in Zambia and expatriates on temporary contracts, and between Hindus and Muslims. Further splits exist between various country, home region, and language backgrounds-people from India versus those from Pakistan, people who speak Gujarati, and those who speak Bengali, or Hindi, and so forth. Within each of these groups, people met for specific religious and cultural events. The white expatriates also sort themselves out into broader regional groups, for example, North Americans, Scandinavians, and then distinct national groups: the British, the Germans, the French, those from the Netherlands, and so on.

The mingling across subgroups that happens at times results largely from shared professional interests. It produces a number of informal circles or cliques, such as the embassy crowd, the development people, university teachers, corporate managers and directors, and missionary circles. In households where both spouses work away from home and in different areas, socializing involves a broader realm of people than in households where only one spouse is wage employed.

While husbands attend meetings of their sex-segregated service clubs, women also have their auxiliary circles and service organizations, such as the American Women's Club, various church groups, the Business and 
Professional Women's Club, the Women's Institute, and the YWCA. Many of these groups have social work as well as recreational functions, and some are places where expatriate women meet elite Zambian women. Groups of women from different residential areas meet informally for recreation and exercise. White expatriate husbands and wives spend more leisure time together than do Asians and Zambians. Yet several white women expressed the view that life in Zambia was hard on marriages and gave examples of couples who had divorced while living there. Support groups of friends and relatives are lacking in Zambia and it takes time to develop new ones. The general fear and insecurity is stressful and takes its toll. One is thrown back on oneself, but there are today, more than during the colonial period, possibilities for interaction across nationality, race, and sex lines which may provide opportunities not before explored.

Patterns of leisure-time activity among the members of Zambian servantemploying households are shaped to a great extent by the household's economic means and are in general more sex-segregated than they are among expatriates. Except for the fraction of Zambian households where the chief wage-earner is in a high-level position, incomes are smaller than those of most expatriate households. Also, there are more strains placed on their incomes, because Zambians have larger families and regardless of economic position they are likely to be additionally burdened by relatives from the extended family in need of support or education. Few Zambians renounce such responsibilities although some high-ranking officials I surveyed did place a limit on relatives they would be willing to support.

Membership in clubs is beyond the means of many Zambian households, so it is those Zambian men who are managers, directors, in the professions, and in upper-level government jobs whom expatriates will meet for games of tennis or golf, for a drink, or occasionally invite for dinner. Except for occasional visits to watch them play and to share a drink with them, the Zambian wives rarely accompany their husbands to the clubs. Husband, wife, and children may attend church together, but for the most part their social networks do not overlap. Women's social life includes women coworkers, neighbors and church friends, and relatives. Some women are members of such groups as the Business and Professional Women's Association and the YWCA, and some are active with expatriate women in fundraising activities for a variety of purposes, including the welfare of children and the plight of poor women in the townships. In the mid-1980s the Zambia Association for Research and Development established itself in preparation for the 1985 meeting in Nairobi that concluded the United Nations Decade for Women. This group has begun to raise critical questions about sex discrimination in the economic and political domain. These efforts involve a small number of professional women who can afford to spend time concerning themselves with social issues. The interactional 
sphere of most Zambian women is more limited. They get together with other women for events that symbolically celebrate their female sexuality - "kitchen parties" before weddings, when the prospective bride's women friends and relations give presents for the new home and and join in ribald song, commentary, and dance to prepare her for her new role as a wife, and baby showers. These parties offer a contemporary parallel to the initiation rites that took place in several of the region's rural societies not so long ago. They are accompanied by much beer drinking and conviviality.

Such events are welcome interruptions of the dreary routine of attending to household needs, often in isolated circumstances. In many Zambian households, husband and wife share little beyond the bedroom. Women are expected to cope with the pressures of maintaining the household, searching out scarce foods, queuing for necessities, without the help or emotional support of husbands. Men still eat separately in many Zambian households, and spend time where and with whom they like, unquestioned by their wives. Women friends offer each other much needed support systems.

\section{Servant Interaction: Households, Neighborhood, and City}

"They don't entertain like we do," say employers about their servants' leisure activities. Obviously not; servants cannot afford to. How they have a good time reflects their low salaries, not some essentially different outlook on life from that of their employers.

Servants' leisure-time interaction takes place in several social arenas which I discuss in turn: in and around the quarters with members of their households; with other servants from the neighborhood and visitors who call on them; in low-income areas across town; and in the city's downtown.

Social interaction within the servant's household is shaped by the ageand sex-based hierarchical division of authority common to most Zambian households. Some servants treat their wives in a very authoritarian manner, prohibiting them from doing tasks that take them far from the quarters. Euclid's new wife, for example, was not allowed to go shopping in a small grocery store some fifteen minutes' walk from their house. Edson was more liberal, or perhaps Gertrude was more independently minded, for she went downtown by bus to do errands and walked to the nearest compound to purchase vegetables at the market. Visitors are entertained with Zambian food prepared by the wife if their hosts can afford it. Otherwise they are given only something to drink. When leaving, visitors are usually escorted to the nearest bus stop, where the host will wait until the bus has arrived, for it is considered impolite to let visitors depart without company. 


\section{Colonial Legacies and Postcolonial Changes}

A lot of socializing takes place outside of the quarters. Men seat themselves on chairs, women and children sit on the ground. Some servants have transistor radios and listen to music or the football games that are transmitted every weekend. Radios and record players are coveted possessions. Listening circles may include visitors and servants from neighbors' houses. When the householders are away at work during the daytime, a good deal of interaction and conversation take place between servants in the neighborhood across garden fences and within yards. They exchange news about the comings and goings of their employers, the imminent departures of some, and the possibilities of getting jobs elsewhere. On weekends in one of the neighborhoods in which I lived, one of the menservants played a homemade guitar, drawing a crowd of children and adult servants of both sexes around him. Euclid was a fine drummer, but it took the arrival of a young relative of the employers, who was himself a music student, for his employers to discover that he had such skills.

Some servants took pride in decorating their interior living space. Although the majority of the servants' quarters described by my assistants as part of the survey looked drab, some servants tried their hands at interior decoration. Walls would feature current or outdated calendars, family photographs, pictures cut out of magazines, and occasionally Zambian curios. Shelves and tables would sometimes support a vase with plastic flowers. One servant in one of the neighborhoods where I lived enjoyed making arrangements of natural flowers and would decorate the employer's and his own living room. A variety of bric-a-brac from the employer's house might be on display as well: cosmetics bottles, discarded plates, and trays.

Radios are coveted possessions, as are record players. When Edson wanted to borrow money to buy a secondhand record player, his employer refused, warning him of the recurrent expenditures he would have for a long time because of the need to purchase records. The employer's refusal reflects a paternalistic concern and an implicit judgment that he knew better than Edson how to handle Edson's money. And his attitude circumvents the central issue: Edson's desire to be able to listen to music, an activity in which he took pleasure, and his freedom to pursue it. Euclid had a different desire: he wanted to buy a secondhand sofa and chairs for his living room and he needed an advance from his wage to do so. His employer advised him against it, primarily because he suspected the furniture was stolen, but also because he considered it an unnecessary item for Euclid to spend money on. Euclid went ahead and bought furniture, although not from the suspect source. Rather than being deliberate attempts at emulating the lifestyle of their employers, these examples show the servants' affective pursuits as well as their desire to have pleasant living surroundings.

Servants who live in the compounds do most of their socializing with 
people in their neighborhoods. Because of their long working days, they socialize mainly on weekends and their half days off. Servants who live in backyard accommodation in the low-density areas have relatives and friends in the compounds and go there to visit. Those who are fond of beer go to the bars and taverns in the compounds on weekends (some employers are familiar with the effects of such visits, as the housework on Mondays may proceed rather slowly). Since the low-density areas rarely feature shops and markets, servants make some of their purchases in the compounds as well. When needing special advice, they also consult experts in the compounds. When Gertrude's smallest child fell ill after a rural visit, she insisted on taking her to the compound for treatment because she feared the child had been bewitched in the village. When the nganga's (African doctor's) treatment did not help and the child got worse, the employer demanded that Gertrude take the child to the hospital where she was treated for a serious case of anemia.

Some servants attend churches in the compounds, and others go to the churches in the town's low-density areas. Euclid was a lay preacher in a suburban Lutheran church; his budget shows how seriously he took the church's challenge to help your poorer fellow men, for from his low wage he managed to give tiny donations at church services. He studied the Bible at home and would call on the madam for clarification of old-fashioned English words. Once, when reading the Old Testament, he asked where Egypt was and what kind of place it might be. When hearing about the Nile river and its delta, he commented that Egypt had to be a wonderful place to keep cattle. Euclid went to church alone, leaving the wife and child behind. Edson would have liked to go to church but was prevented from doing so by the madam, who felt she would be inconvenienced if she did not have a full-time servant at work on Sundays.

There are few shops in the low-density areas, and servants have to purchase many necessities downtown or at markets in the compounds. Because of the scarcities of basic consumer goods and the limited diversification of the local manufacturing sector, servants and their employers shop in many of the same stores when buying necessary household items such as cooking oil and bath soap, shoes and clothes, and pots and blankets. Because of their low wages, servants have little purchasing power in that market and, knowing the prices, they are forcefully reminded of their poverty when unloading their employers' cars. A week's supply of goods in many cases costs more that the amount a servant receives for a month's work.

Lusaka's hospital, most clinics, banks, and institutions of the state are spread across the downtown area at a distance from most residential areas. Visits to them place servants in contact with a broad range of people and prompt them to develop interactional skills and exercise civic duties that 


\section{Colonial Legacies and Postcolonial Changes}

have little to do with their work as servants in private households. Edson appeared in court to testify on behalf of a relative. Unless they coincide with the servant's full or half day off, visits to such institutions directly interfere with the work routine and they inevitably annoy the employers. So do the unanticipated claims servants sometimes make for time off to attend funerals or call on a sick relative, especially when an out-of-town visit is involved. Funerals are elaborate affairs in Zambia, requiring a person's attention for more than just a couple of hours and an outlay of money as well. From the servant's perspective, a funeral is an occasion for showing respect for the deceased on the one hand and for strengthening ties to the surviving kin on the other. Because of classificatory kinship, a servant may have several persons in the same relationship to him as father, or as mother, or mother's brother, and so on. In the view of many employers, servants use funerals to get time off, and some employers limit the number of funerals for which they will be willing to release their servants.

Unlike their employers, servants have no discretionary budget to use on entertainment such as movies and football games, but their interests bring them together on rare occasions. The sportsground in the residential area off the University of Zambia campus in Lusaka was in 1983 the stage for a football game between the area's servants and their employers. Sports, like the hunting trips that colonial officials would take accompanied by their servants when on up-country tours, make men equal competitors and temporarily conceal the structure of inequality in society at large. To improve their position in that wider setting, servants struggle not only against their employers but on other fronts as well.

\section{Servants, Class, and Development Questions}

The place of domestic servants, qua wage workers, has remained problematic after independence although the class divisions within Zambia have grown more conspicuous. Whether or not servants today constitute a class and, if they do, how class consciousness is formed is an open-ended question. Attempts to answer it must take into consideration postcolonial economic developments that have adversely affected rural livelihoods and severely depressed the wage-labor market. These developments significantly influence servants' circumstances and future prospects. Servants' struggle to improve their situation takes place on three fronts: at work, in their own households and in social interaction, and in public in their relation with agents and institutions of the state. This threefold struggle, rather than any previous identification of servants as a class in terms of their relation to the means of production, is relevant to the explanation of the process of class formation and how class consciousness is made or unmade.

For how long will servants remain content with "half a loaf," saying, as 
many did when interviewed, that it is better than none? Today in Zambia the class division between worker and employer is no longer masked by race. Servants consent to an exploitative work regime out of fear of losing their jobs. Yet while consenting, they also actively contest the hierarchical rules of the game, and class distinctions enter into the relationship between servant and employer and help to politicize personal relations. Through their work, servants become excellent judges of character and skilled at sizing-up their employers. They use this skill politically, working no more and no longer than they themselves consider appropriate to their low wages. They bend the rules established by the employer to suit their own interests. "Go slow" routines, deliberate misunderstandings, apparent forgetfulness, not answering intrusive questions are all ways servants actively contest their labor regime while consenting to it so as not to lose their "half loaf." Work-related behavior that appears to be part of a personal survival strategy is thus directed against the employers and indirectly against the state, which for so long has taken little interest in what to its representatives appears to be merely personal squabbles in private households.

Servants' political outlook is shaped not only at the workplace but also by interactional activities in their own households and at leisure. Their attempts to keep wives at home and out of work reinforce the conventional hierarchical gender division and make the man servant an autonomous actor at least within his private household domain. It relieves him from the double burden of performing paid domestic labor as well as private household work, and enables him during his limited time off to interact with people who earn their living in different ways.

The servants in the survey spoke about the people they associated with. They were servants in the neighborhood, relatives and friends in the compounds, and churchmates. Their emphasis that they did not choose their friends because of shared ethnicity but "because of the person" may reflect the combined impact of two factors: the official political ideology of "One Zambia, One Nation," and the multiethnic character of Zambia's towns, where residential areas show little ethnic clustering. Spending leisure time in different neighborhoods, with residents in the compounds, attending church, and visiting shops and government offices gives servants a view of what lives outside of domestic service are like, and they use this knowledge for critical comparisons. They know what the gap is between their wages and those of many other workers. They are concerned with how to improve the livelihoods of their children when their own circumstances are so poor. Those who are literate read the newspaper while the employer is at work and are aware of labor unrest and strikes in other fields. Many servants vote in elections; they know who the candidates and what their platforms are (these platforms have never included issues specific to servants).

What are the prospects for class action among this category of workers in 
Zambia today? Servants are one of the few remaining segments of the Zambian labor force which are not unionized. But as noted earlier, there are several factors that may militate against collective mobilization among servants. In this monopsonistic market employers have tremendous power. Because of the ready availability of replacements of what has become deskilled labor, servants fear losing what little they do have. They refrain from complaining when hiring and firing is heavily influenced by personal factors.

Regarding the question of labor unions, 36 percent of the servants in my survey argued that servants definitely should have a union, that it would help improve their work conditions. But 48 percent said they doubted a union would be effective. Another 13 percent were even more negative, saying that unions would never work; relationships in domestic service would always be determined by the employers. And 3 percent simply said they would not be able to join a union because they could not afford to pay a union membership fee. Nevertheless, the union issue has engaged some servants' minds in the past and continues to do so at present. Some servants have tried to organize in the hope of improving wages and work conditions and to force employers to pay their ZNPF contributions. For in practice, matters between employers and servants continue to be handled at the individual level without regard to the legislation embodied in the Employment and the ZNPF bills. One such effort was the formation in 1973 of the National Domestic Houseservants Association of Zambia, the result of activities among servants in Lusaka (although it seems at one time to also have involved a group on the copperbelt, the Copperbelt Domestic Servants' Association). The Lusaka group, claiming four hundred members in 1974, aimed to protect, improve, and legitimate the professional interests of domestic servants. It argued for stricter compliance with the ZNPF registration scheme, higher pay, better living quarters, and the provision of uniforms. The group also called for the formation of UNIP party branches in the low-density residential areas so that servants could obtain party cards (which are needed in order for a person to rent a house in a lowincome township). The association's officials felt that without party membership cards, servants would be discriminated against in the housing market. According to Fanwell Mukatulwa, chief spokesman for the association, "without forming branches in these places of so-called Apamwamba townships or yards, the party and government cannot know the enemies of the party." 8

8. This account is pieced together from handwritten letters filed in the Lusaka offices of the Times of Zambia and published write-ups on July 19, 1973; August 17, 1973; April 1, 1974; November 25, 1974; January 17, 1975; March 18, 1978; June 10, 1978; September 20, 1978; and December 23, 1978. It is unclear from these communications whether or not the association ever registered with the Registrar of Societies, although an intent is indicated several times. 
By 1979, however, the Houseservants Association withered away as its predecessors had in the past. Fanwell Mukatulwa appears to have obtained a better job in Livingstone with the Fiat motor assembly plant, ${ }^{9}$ and in 1983 no one-neither union oficials nor servants interviewed-remembered the association. There may have been other attempts by servants to organize. As far as I know, the most recent effort at union formation took place in Kitwe on the copperbelt in October 1983. Reacting to it, Newstead Zimba, the general secretary of the Zambia Congress of Trade Unions, offered the comment heard many times during the colonial period, that a servants' union would be "unmanageable." He remarked (erroneously) that servants were "under" the National Union of Hotels and Catering Workers. His condescending answer to a servant who suggested the formation of a union was that "if he was looking for a job he should go to the Hotel and Catering Workers rather than mislead houseservants." 10

The record of other countries suggests that unions for servants can be "managed." In several Latin American countries servants have formed associations or unions. In Zimbabwe a union was established for domestic workers immediately after independence in 1980 at the same time that the minimum wage was raised. South Africa (until recently) had a number of local domestic servants' associations which in December 1986 were combined as a registered labor union under the Congress of South African Trade Unions. Trade unions for servants can certainly be established and registered, as these examples show, but whether they can appreciably improve the working conditions of servants and upgrade their position in relation to other unionized groups remains to be seen. Given the postcolonial history of trade unionism in Zambia and the attitudes of officials, it is doubtful that a trade union for servants would be effective. Furthermore, statutory instruments barring strikes and free collective bargaining have diminished the influence of trade unions.

Servants failure to form unions does not necessarily mean they lack class consciousness. They did try to fight when they could both before and after independence, indicating that they considered their work position problematic and wanted to change it. Their class consciousness during the colonial period may perhaps be best described by Gluckman's term situational, ${ }^{11}$ and it did produce some features of an urban servants' work culture and status system that influenced their activities in some contexts. Servants were snobs, as one retired employer recalled. They took their status from their employers and they had a hard time accepting the job of

9. According to the registration files of the Zambia National Provident Fund.

10. "Kitwe Domestic Servants Form Union," Zambia Daily Mail, October 18, 1983, p. 3.

11. Max Gluckman, "Anthropological Problems Arising from the Industrial Revolution," in Social Change in Modern Africa, ed. Aidan Southall (London: Oxford University Press, 1961), pp. $68-70$. 


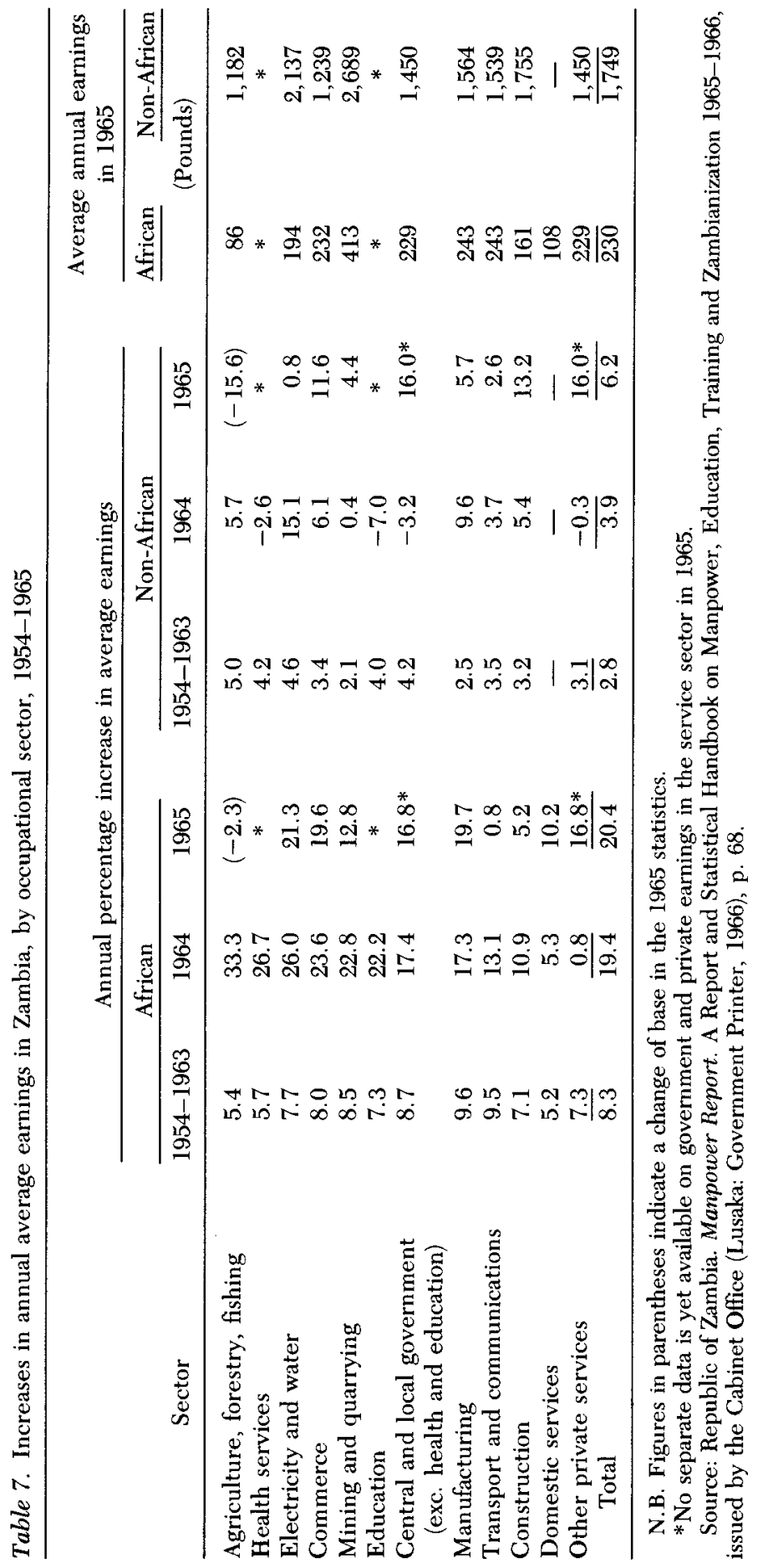


serving for African guests in white households when the political climate began rapidly to change in the 1950s. Several long-time servants enjoyed peaceful retirements on the support of good employers, and most of their children had gone to school and helped support them as well. But when engaging in class action, consciousness had a different focus. For there was a vast generalized urban working class beyond domestic work with whom servants could and did at various times develop relationships. The circumstances that made such shifts possible have changed to a great extent today where servants derive little material benefit from sharing their Zambian employers' status. In objective terms, servant wages are at the bottom level of wage scales in Zambia (see Table 7). They compare in many ways with the level of incomes made by informal sector workers. The "slave job" aspect about which servants speak may refer to more than just their low wages; it may imply a notion about an unremovable job status they are particularly concerned not to pass on to their children. Very few of the servants interviewed in my research were themselves the sons and daughters of servants. Most of them objected strongly to the idea of their own children working as servants, and within their limited abilities they tried to do what they could to prevent this. Their concern about exiting from domestic service, in their own lifetime or through their children, suggests that a consciousness focused on this particular occupation is yielding to a renewed realization of the shared problems that confront working-class lives in urban Zambia.

In the view of most of the servants interviewed, domestic service is "just another job", although a disliked one that at the present time puts men and women to work on different terms and in unlike ways. The growing number of women and young people who are entering service since independence has the potential to create factions within the ranks along lines of generation and gender. Because of its economic vulnerability each faction may continue simply to try to preserve its "half loaf." If the economy continues its downward turn, domestic servants may hold on more tenaciously to their disliked jobs as ever fewer options become possible. If as a result, sons and daughters of servants increasingly follow in their parents footsteps and a servant class develops, it may perhaps devise new and radical means to protect its interests.

\section{Development Questions}

The kind of development that might solve Zambia's problems, including those of servants, would entail an overall "change process characterized by increased productivity, equalization of the distribution of the social product, the emergence of indigenous institutions whose relations with the 


\section{Colonial Legacies and Postcolonial Changes}

outside world and particularly with the developed centres of the international economy are characterized by equality rather than dependence or subordination." 12 In this ideal world, everyone would be productively engaged and earn a living wage without having power wielded over them by those richer than they, and women would not be dominated by men. The availability of alternative labor opportunities would make the servant market a sellers' market, and householders would have to pay living wages for whatever services they contracted.

These utopian conditions have not been achieved anywhere. They were approximated in the United States during a period of economic growth when native-born American women left service. They were replaced by immigrant labor. This continues to be the case today, as it is in much of northwestern Europe. So it was in Nigeria, to give an African example, during the oil boom, when indigenous Nigerians left domestic service for better jobs, and alien Africans succeeded them as household workers. ${ }^{13}$

Given the poor economic performance of the Zambian economy, no utopian scenario is likely to be realized. The process currently ongoing in the West, the movement of capital into service industries, including private domestic service, transforming them into arenas of capitalist relations where contractually employed workers are freed from the ambiguous personalized regime characteristic of domestic service, also belongs to a distant and perhaps unforseeable future. One is forced, then, to confront the question of how to reform this occupational domain within the wider context that presently structures it. Barring an overnight restructuring of the Zambian economy and its dependent relationship with outside markets, and perhaps the outright disappearance of domestic service, what can be done to ensure servants a living above bare subsistence level? Should the employment situation improve somewhat, men are more likely to be the beneficiaries than women, given women's secondary status in the labor market historically. In all likelihood an improved situation would simply mean that more women would move into the male stronghold of general household work as men moved out and up. Such a shift would likely be accompanied by a deemphasis on sexuality in the cultural construction of women servants' gender role. But in my own view, domestic service will continue to grow, with its current division of labor by gender. The processes ongoing in Zambia today will sustain the growth of the population segment who now employs servants. These processes will widen the gap

12. E. A. Brett, Colonialism and Underdevelopment in East Africa: The Politics of Economic Change, 1919-1939 (London: Heinemann, 1973), p. 18.

13. During the oil boom, Nigerian servants priced themselves out of the market, leaving it to alien Africans who were willing to work for much reduced wages. According to one source, after the expulsion of aliens in 1983, Nigerian servants changed the rate to what it had been before the aliens undercut it. "Of Aliens and Foreigners," African Business, June 1985, p. 23. 
between those who are economically well situated and those who have nothing but their potential to labor.

Employers, Zambians and expatriates alike, are quick to assure you that they at least provide poor people with a job. Their implicit rationalization, that it is better to work than not to work, may be correct, but for the wrong reasons. To be sure, a large number of people are employed. But their work represents far more than a way of passing time. It contributes appreciably to the social welfare of the employing classes and makes available to them at extremely low cost child care and household maintenance facilities that neither the state nor private business have been able or willing to furnish. Some observers have referred to domestic service as a form of "misemployment," meaning the underutilization if not wasteful use of labor that is unproductive. ${ }^{14}$ But except for the very few households in postcolonial Zambia who employ large domestic staffs in part for public display, the work of most servants does not so much represent underutilization and waste as naked exploitation of labor power. In return for substandard pay, servants perform tasks that wealthier households cannot do without.

Servants' lives could be improved appreciably, if employers would observe the few rules and regulations that in postcolonial Zambia are supposed to guide the employment of servants, and which in theory should improve their conditions compared with the colonial period. Could labor union activity by servants help them to force their employers to observe these requirements? There is no reason to believe that unionizing would be the only or best way in the future to seek changes in domestic service. But just because attempts to wrest improvements from the system have failed in the past does not mean they always will. The political climate has changed and new links have been forged between the existing unions and the state in ways that do not always benefit the common worker. Economic conditions have also worsened. Servants are realizing that their opportunities to leave domestic service have declined and that the broad mass of unskilled workers are not doing much better than themselves. Under these conditions, servants may become increasingly impatient with their "half loaf" and begin to frame their claims for improvements in unconventional ways such as demonstrations and riots. In my opinion, plans for improvement must address the connection between women's deteriorating wage labor conditions in service as compared with men's and their roles as unpaid household workers, as mothers and wives.

Whatever else development might mean for domestic service in Zambia, it means choice and autonomy. Both can prove subversive to people in

14. Alan Gilbert and Josef Gugler, Cities, Poverty, and Development: Urbanization in the Third World (London: Oxford University Press, 1982), pp. 68-69. 
power-men who are heads of state and men who are heads of households. Those in power - heads of households, those who employ servants - and men and women servants play different and often contradictory roles in shaping the domestic service domain in the way it is presently structured. But this structure is not preordained or unchangeable. Everyone will have a part to play in reforming domestic service. At least in the short term, men and women servants and their male and female employers will have to participate in removing from this occupation the aspects of personal subordination and exploitation which deprive servants of their sense of personhood. 